\title{
Mobile medical emergency units in France-part I
}

\author{
N DROUET
}

On ramasse un blessé (We pick up the injured)

On transporte un agonisant (We carry the moribund)

On hospitalise un mourant. (We hospitalise the dying).

Professor M Arnaud

Doctors worldwide are becoming increasingly aware of the need for transporting some patients under medical supervision and optimum conditions by using mobile medical or paramedical units. With proper treatment and resuscitative procedures before their arrival at the casualty department, patients are less likely to die at the roadside or in an ambulance. Furthermore, the condition of patients which is already precarious is less likely to deteriorate. In this day and age patients should not arrive at an accident and emergency unit in a worse clinical state than when they left the accident.

Mobile emergency medical units have been set up worldwide and particularly in France. The unit at St Julien-en-Genevois is a typical example (see part II).

\section{Background}

The first civilian mobile medical teams came into being in 1898 in Moscow $^{1}$ to deal with victims of road accidents. Today, in Moscow, Leningrad, and Kiev telephone calls for medical emergencies are processed by trained nurses and doctors at a central station switchboard; the required unit or "skoraya" is then sent from the appropriate substation. In Moscow there are 22 substations, one for each of the city's administrative units. One "skoraya" caters for about 35000 people.

Many countries now possess an efficient emergency system, with a single national telephone number, such as 999 (Britain), 100 (Germany), and 90000 (Sweden). In Switzerland the "Garde Aerienne Suisse de Sauvetage" (the Swiss air rescue guard) is responsible for the rescue and transport by air of many mountain and traffic accident victims under medical supervision. ${ }^{2}$ In Germany, mobile medical units have existed in Heidelberg and Mainz since the mid-1950s. ${ }^{3}{ }^{4}$ In Belgium and Italy, an increasing number of ambulances have resuscitation equipment and are manned by a doctor. In Britain specialised mobile medical units, such as obstetric and paediatric flying squads, coronary care $^{5}$ and intensive care ambulances, ${ }^{6}$ and general practitioner and hospital-based mobile accident services ${ }^{7}{ }^{8}$ are provided. There are also the flying doctor services in Africa and Australasia and other mobile health units in Israel, ${ }^{9} \mathrm{Japan}$, and the USA. ${ }^{10-12}$ For example, in San Francisco there are 20 paramedic resuscitation ambulances for a population of $700000 .^{13}$

Department of Anaesthetics and Intensive care, Nancy Teaching Authority, Vandoeuvre, France

N DROUET, MA, senior house officer

\section{FRANCE}

In France ${ }^{13}$ mobile medical emergency services originatedoे from the many military campaigns over the years. Since the days of Philippe le Bel (thirteenth century), barbers and surgeons $s_{\infty}$ followed the armed Forces. Henri II (1550) created the first. mobile hospital for the war wounded. The Paris-based regimentef of firemen, now the "Brigade des Sapeurs-Pompiers de Paris," was created by Napoleon $I$ in 1811 and together with other $\overrightarrow{0}$ bodies of firemen throughout France was given the responsibility for emergency services in all human disasters in 1884. The fireo services still have an important place in medical emergencies, especially in those that occur in public places and on the highway.

In 1883 the civil and police authorities in Paris created aه⿱乛龰 system of two horsedrawn ambulances for the transport of $\overrightarrow{0}$ infectious patients between hospitals. The idea of transportingo patients under medical supervision did not become official until a ministerial circular in 1949. In the years 1955-6 Professor MO Cara, now director of the "Service d'Aide Medicale Urgente" (Paris unit) (department of emergency medical services) organised the transfer under medical supervision of patients with poliomyelitis who were on ventilators. Also, in that year, $\varrho$ Professor P Bourret, now director of the "Service Mobile $\overrightarrow{0}$ d'Urgence et de Reanimation" (the mobile emergency and 3 resuscitation service) at Salon, established the first mobile surgical units for road accident victims at Salon-de-Provence. In? $1960^{14}$ the Minister of Health recommended the extension of these services, and in $1965^{15}$ hospital-based mobile rescue units together with emergency treatment and resuscitation units:were established. The mobile units had to have a minimum staff of an ambulance driver and either a nurse or a doctor; anaesthetists and anaesthetic and intensive care nurses were 3 preferred. The vehicles were to be equipped with a radio ando resuscitation equipment. The hospitals had to acquire these units either directly by buying the necessary equipment oro through agreements with local organisations such as the French Red Cross, the local civil defence, or private ambulance companies. Only a few hospitals were able to comply with the ${ }_{0}^{N}$ decree. Not until 1969 and 1972 were government grants provided for the buying of equipment, the building of premiseso and heliports, and the running costs for these units.

\section{Service d'Aide Medicale Urgente (department of emergency medical services)}

A department of emergency medical services was first defined in September $1973^{16}$; it was to be hospital based, preferably run by an anaesthetist, and had to contain three basic elements:

Operational-mobile units, as defined in the decree of 1965,0 a heliport, offices, and on-call rooms.

Reception-a unit for the sorting and immediate treatment of patients and space for inpatient care. 
Resuscitation-an intensive care unit, as defined in the circular of $1965 .{ }^{17}$

Various plans for a law legally defining the department, its functions and activities, were proposed in the 1970s. ${ }^{18}$ The agreed basic definition of "emergency medical aid" was: (a) a permanent telephone-monitoring and radio-monitoring service able to answer all inquiries and to give advice and assistance to all those injured or ill and to pregnant women; $(b)$ a service able to give the necessary treatment to a patient at the scene of the accident or illness; $(c)$ a service able to transport the patient to an appropriate treatment unit if necessary; $(d)$ a service able to provide doctors, the police, and health workers with information on the possibilities of treatment and admission of emergencies, as well as duty rotas for doctors, chemists, nurses, and ambulancemen; and (e) a service able to educate and train its staff.

In France each citizen is free, within reason, to choose a treatment unit and a doctor; however, a patient requiring a cardiology bed cannot ask to be admitted to a unit without cardiology beds.

\section{NATIONAL ORGANISATION}

The official ministerial plan is to have at least one department of emergency medical services for each "departement" (administrative unit equivalent to a county). In July 1980 a total of 86 "departements" had a mobile medical unit. ${ }^{19}$ There are nine "departements" without an emergency mobile medical unit; this is provided by a neighbouring "departement." Ideally, a mobile unit should be able to reach the scene of distress in less than 30 minutes by road or by any other means available in any part of the country. ${ }^{20}$ This is as yet not the case.

Nationally, there are two types of department ${ }^{21}$ : a sector and a co-ordinating or regional unit, whose functions includes those of a sector unit as well as (a) the co-ordinating of the work of the sector units in its region, particularly evacuations by helicopter; $(b)$ the provision of help, medical, or otherwise, to its sector units, as required; and $(c)$ the training and education of all staff concerned in the work of the service. By definition a co-ordinating unit is based in a regional hospital.

Because France has a wide range of geographical features, many units endeavour to have staff, medical and paramedical, trained in the special techniques required for rescue in such varied circumstances. For example, two doctors from the unit in Toulouse, both trained in potholing, had to descend to a depth of $400 \mathrm{~m}$ with a total distance underground of $2 \mathrm{~km}$ in a potholing accident. ${ }^{22}$ Similarly, doctors in the Amiens unit had to contend with extremely difficult conditions in the rescue of a sea-captain who had lost a hand in an accident on board ship during a storm. ${ }^{23}$

All the service units throughout France now have a place in the disaster plans of each "departement," the "plan catastrophe" (major accident plan) and the "plan Orsec" (disaster plan). The disaster plan can only be initiated by the "prefect" of the area concerned. The medical care of the patients and their transport and admission to hospital is carried out by two units, one at the field headquarters and the other at general headquarters at the service's switchboard. The role of the former, usually staffed by a senior anaesthetist, is the sorting of victims; that of the latter is to direct the ambulances to the correct admission units throughout the town or area concerned. Several experiences of the "plan catastrophe" occurred after several plane crashes in the early 1970 s. ${ }^{24}$

\section{FINANCES AND ECONOMICS}

The budgets for the service units, although independent, come under the supervision of the hospital administrative authorities. This has allowed the units to evolve more or less independently of their parent hospital. The Ministry of Health provides large sums of money to the service fr 10 million ( $£ 1$ million) in 1972 and fr 40 million ( $£ 4$ million) in $1975^{18}$-but only since 1966 , one year after the original decree, has the Minister of Health offered grants up to $50 \%$ of the cust of buying the radio equipment. ${ }^{25}$ Six years later further substantial grants, including up to $70 \%$ for the building of heliports, were proposed. ${ }^{26}$ Other sources of income include grants from the "department" and other bodies and from the patients themselves, who pay for their transport costs.

Most units are short of money, despite the grants and, of course, increasing personnel costs do not help. When everything is considered, though, the service may not be as expensive as it is thought. The director of one unit ${ }^{27}$ has estimated that, for his "departement" the cost in 1980 was fr 5.50 ( $£ 0.57)$ yearly for each inhabitant.

One major economic aspect of the service is the relationship between its running costs and the amount of money saved in human lives. ${ }^{28}$ In 1978, it was estimated that a unit with a total annual budget of fr 3 million $(£ 300000)$ became cost-effective when more than 10 lives were saved a year, since the cost to society of a road traffic accident death was estimated at fr 380000 $(£ 40000)$. Although this logic is open to argument deaths due to road traffic accidents (road accidents being the major cause of death in the age range 25-30 years) are a major sap on the country's future economic development and power.

\section{The "Centre 15"}

The "centres 15" attempt to centralise, in each "departement," all emergency medical calls. ${ }^{20}$ Their official function is to answer (a) all medical distress calls; (b) all calls for general practitioners; and $(c)$ all inquiries from medical practitioners on the availability of hospital (public and private) beds, ambulances, and drugs. The sorting of these calls is carried out by some doctors from the medical emergency service and by general practitioners trained in this work. This is in fact the most important job of the "centres 15." In the sorting of calls by the medical emergency service the "regulateur" (sorter) (a) monitors the health wavelengths and telephone numbers; $(b)$ sorts calls according to the emergency described; $(c)$ shunts calls to various units, such as the patient's own general practitioner, the duty general practitioner, the "Service Mobile d'Urgence et de Reanimation" (mobile emergency and resuscitation service), the poisons centre, private or hospital ambulances, and the fire services; $(d)$ gives medical advice; and (e) co-ordinates the work of the mobile emergency and resuscitation service.

The first experimental "centre 15" started work in Troyes in $1980 .{ }^{29}$ In September of the same year another was set up in Rouen. Plans for a further service are well advanced in Grenoble, whereas those in Blois have had to be dropped because the town's general practitioners do not agree with the idea. These experiments depend very much on the co-operation of many services but mostly on the general practitioners, some of whom fear losing their patients and their fees. In fact, calls to the "centre 15" not requiring an ambulance from the service but only the visit of a general practitioner are shunted by radio or telephone to the general practitioner on duty, who always leaves a note for the family's own general practitioner.

Thus, although centralised emergency medical services exist in many countries, most of them fail in three ways ${ }^{30}:(a)$ the emergency telephone number is common for all the public services; $(b)$ the general practitioners do not participate in the system; and $(c)$ there is a lack of medical secrecy, especially in the presence of the police and the fire services. It should be very interesting to see if the "centre 15" fares any better, considering the difficulties being created by the general practitioners in some towns.

\section{References}

${ }^{1}$ Queralto C-M. Pour l'amelioration de l'urgence medicale; un numero d'appel national, le 15. Medical Thesis. Faculté de Medecine, University Paul Sabatier, Toulouse. 1977. 
2 Buhler F. L'histoire de la Garde Aerienne Suisse de Sauvetage. La Revue des $S A M U$ 1980;3:191-200.

${ }^{3}$ Emmanuelli X. Que sais-je? Medecine et secours d'urgence. Paris: Presses Universitaires de France, 1979.

${ }^{4}$ Gogler E. Les accidentes du traffic routier. Basle: Documenta Geigy, 1964.

5 Vetter NJ, Pocock S, Julian DG. Measuring the effect of a mobile coronary unit on the community. Br Heart $\mathcal{f} 1978 ; 41: 418$.

${ }^{6}$ Aitkenhead AR, Willis MI, Barnes WH. An economical mobile intensive care unit. $\mathrm{Br} \mathrm{Med} \mathcal{F}$ 1980;280:1219-21.

${ }^{7}$ Davy RG. Immediate care: the Hillingdon Hospital mobile accident team. Br Med f 1980;281:121.

${ }^{8}$ Morris DL, Cross AB. Is the emergency ambulance service abused ? $\mathrm{Br}$ Med $\mathcal{F} 1980 ; 281: 121$.

${ }^{9}$ Silverston PP. Emergency medical services in Israel. Injury 1979;11: 90-100.

10 Sherman MA. Mobile intensive care units: an evaluation of effectiveness. f $A M A$ 1979;241:1899-1901.

11 Stang JM, Fulkerson PhK, Lewis RP, et al. Effectiveness of advanced paramedics in a mobile coronary care system. $\mathcal{F} A M A 1979 ; 241$ :1902-4.

12 Bergner L, Hallstrom A, Eisenberg MS. Cardiac resuscitation in the community: importance of rapid provision and implications for program planning. FAMA 1979;241:1905-7.

13 Horwitz M. Le 15 à San Francisco. Le Generaliste 1980;249:18.

14 Ministère de la Santé. Circular. Bulletin de la Santé et de la Famille. 27 Jul 1973.

${ }^{15}$ Pompidou G. Decree No 65-1045. Journal Officiel de la Republique Francaise, 2 Dec 1965.

${ }^{16}$ Ministère de la Santé. Circular. Bulletin de la Santé et de la Famille, 4 Sept 1973.
17 Ministère de la Santé. Circular. Bulletin de la Santé et de la Famille, 13 Aug 1965.

18 Cettour-Baron G. L'hôpital hors les murs: contribution à l'ètude d $\mathbf{Z}$ l'aide medicale urgente en France. Doctoral Thesis. Université de̊ Sciences Sociales de Grenoble, 1978.

${ }^{19}$ Anonymous. List of the SAMU and SMUR functioning. Revue des $S A M U 1980 ; 3: 242-6$.

${ }^{20}$ Ministère de la Santé. Circular. Bulletin de la Santé et de la Famille, Feb 1979.

${ }^{21}$ Ministère de la Santé. Circular. Bulletin de la Santé et de la Famille, Feb 1965.

22 Batut $M$, Heib JL, Pinta C. Un accident sous la terre. La Revue des SAM@

1980;3:203.
${ }^{23}$ Milhaud A, Nemitz B, Buffet JP. Evacuation sanitaire heliportée ave treuillage. La Revue des SAMU 1981;4:151-4.

21 Wrobel J. SAMU 94 et catastrophes. Medical Thesis, Universite de Va? de-Marne, 1978

${ }^{25}$ Ministère de la Santé. Circular. Bulletin de la Santé et de la Famille, $2 \overline{\overline{6}}$ Jul 1966.

${ }^{26}$ Ministère de la Santé. Circular. Bulletin de la Santé et de la Famille, $1 \mathbf{\Phi}$ Jul 1972 .

27 Horwitz M. Centres 15: les SAMU se fachent. Le Generaliste 1980;261:36

28 Coirier R Les SAMU: financement et economie. Cahiers Francais 19780 188:33-8.

${ }^{29}$ Anonymous. Le premier centre 15 est entré en service dans l'Aube. $L_{\vec{c}}$ Quotidien du Medecin, June 3 1980:8.

30 Bonhomme P. Centre 15 experimental de Rouen. Medical Thesis, Facul Mixte de Medicine et de Pharmacie de Rouen, 1979.

(Accepted 30 April 1982)

\section{Mobile medical emergency units in France - part II}

\section{N DROUET}

Pour l'urgence, c'est déjà parti (If it is an emergency, we have already left)

Pour l'impossible, nous partons immediatement (If it is to attempt the impossible, we are leaving now)

Pour le miracle, nous demandons quelques instants (If it is to work a miracle, we ask a few moments).

Dr P Cadoz*

St Julien-en-Genevois is a small town on the Franco-Swiss border, five miles from Geneva. Its borough has about 7000 inhabitants and it has a hospital of 550 beds for a population of 70000 people. The mobile medical emergency unit based at this hospital covers about the same area (fig 1), which is mainly rural with some plains and low mountains. There is some industry, notably at Bellegarde; a section of the Lyon-Geneva motorway passing Bellegarde is due to open in 1982. The "Centre d'Etudes et de Recherches Nucleaires" (Centre for Nuclear Studies and Research) near Geneva has plans for a major construction site which will involve tunnelling under the French Jura. St Julien is at a major European crossroadsbetween northern and southern Europe and western and southeastern Europe. Consequently, there is very heavy lorry and holiday traffic in both winter and summer.

\section{Service Mobile d'Urgence et de Reanimation (mobile emergency and resuscitation unit)}

The mobile emergency and resuscitation unit at St Julien was established in February $1977 .{ }^{1}$ Despite a modest beginning, the unit is now called on two or three times a day. Because of

*Service d'Aide Medical Urgente (Grenoble).

Department of Anaesthetics and Intensive Care, Nancy Teaching

Hospital, Vandoeuvre, France

N DROUET, MA, senior house officer the distances covered, each call takes between 30 minutes and two hours. If a lengthy rescue procedure is required, such as extricating a driver from his flattened car, the time can be considerably longer. The helicopter can be used to reduce this time, but to transport a patient to a teaching hospital at Lyo or Grenoble takes about one hour's flight time each way.

\section{PERSONNEL}

The medical personnel of the unit includes two hous officers detached from the armed Forces for the duration of thent military service with $2-3$ months special training in a regiona mobile emergency unit; one or two senior house officers anaesthetics and intensive care; and two consultant anaesthetistso Only one house officer is on duty at a time. Should a secon\& doctor be required the senior house officer is called. The consultants are available also as reinforcements if more thas two calls are received simultaneously or in the event of a majof accident or a serious intensive care problem at the scene of th accident. Finally, the house officer second-on-call for the hospital can be called on, particularly for transferring patients between hospitals.

The paramedical personnel include one nursing sister; fiv? nurses from the accident and emergency unit (including one nurse in charge of all the medical equipment of the unit three paramedics from the accident and emergency unit ang intensive care units with an ambulance driver's diplom including the chief technician; and three other paramecii with first-aid certificates. 